Pakistan Journal of Humanities and Social Sciences

April - June 2018, Volume 6, No. 2, Pages 205 - 220

\title{
Moderating Role of Organizational Justice between Emotional Exhaustion
} and Job-Related Outcomes

\author{
Ayesha Shahid ${ }^{1}$, Qasim Ali Nisar ${ }^{2}$, Muhammad Azeem ${ }^{3}$, Waseem Ul Hameed ${ }^{4}$, Sajjad \\ Hussain ${ }^{5}$ \\ ${ }^{1}$ MBA, Department of Business Administration, University of Sargodha Gujranwala campus, \\ Pakistan \\ ${ }^{2}$ Lecturer, Superior University Lahore; PhD Candidate, School of Business Management, \\ Universiti Utara Malaysia \\ ${ }^{3} \mathrm{PhD}$ Scholar, College of Business, School of Business Management, Universiti Utara \\ Malaysia \\ ${ }^{4} \mathrm{PhD}$ Scholar, School of Economics Finance \& Banking, Universiti Utara Malaysia \\ ${ }^{5} \mathrm{PhD}$ Scholar, School of Economics Finance \& Banking, Universiti Utara Malaysia
}

\begin{abstract}
Previous studies anticipated that there is need of justice in educational institutions in order to protect the academicians' psychological as well as emotional needs under teaching profession. Therefore, the purpose of current study is to examine the moderating role of organizational justice between the relationship of emotional exhaustion and job-related outcomes (Teachers' Learning, Organizational Commitment, and Organizational loyalty). In order to accomplish this purpose, the survey questionnaire method was used. The study is quantitative, descriptive and cross-sectional in nature. 250 respondents were selected by applying simple random sampling. Results indicated that emotional exhaustion is significantly and negatively related to teachers' learning and loyalty. Meanwhile, findings divulged the negative association between emotional exhaustion and teachers' commitment. Moreover, results also enlightened that organizational justice (distributed justice, procedural justice, and interactional justice) significantly moderate on the relationship of emotional exhaustion and job-related outcomes (Teachers' Learning, Organizational Commitment, and Organizational loyalty). This study enriches the body of knowledge regarding the moderating role of organizational justice as previous studies almost ignored it. It also gives insight understanding regarding the role of teachers' emotional exhaustion towards their learning, loyalty, and commitment. Additionally, On the basis of these finding, organizations can make their employees more committed and loyal by reforming policies about organizational justice.
\end{abstract}

Keywords: Emotional exhaustion, Teachers' Learning, Organizational commitment, Organizational loyalty, Organizational justice. 


\section{Introduction}

Every nation required quality education by qualified teachers but recent researchers have observed the shortage of qualified teachers (Nett, Goetz, \& Hall, 2011). Indeed, the psychologists proved that the teaching profession demands emotions and has been considered the most stressful profession (Dicke et al., 2014). Furthermore, some studies observed the positively affective emotions lead to constructive learning outcomes e.g. increased motivation level, enthusiasm etc. and negatively affective emotions cause destructive outcomes e.g. higher levels of burnout, lower level of commitment, increased teacher attrition. Emotional exhaustion has been deemed a core facet of burnout(Diestel \& Schmidt, 2011). Therefore, it has been a remarkable influence on teacher's learning. Mostly, the teachers found to be the overwhelmed by their stressful and irregular activities within a workplace. In result of which they felt exhausted that cause lower performance and lower teachers learning as well (Hochschild, 2012).

Academicians are highly observed to be engaged in experiencing emotional and psychological stressors in the teaching profession. Therefore, the academicians face depression, job dissatisfaction, low productivity, absenteeism and turnover intentions cause of high stress and burnout in the institutions(Ohue, Moriyama, \& Nakaya, 2011). Practically, it has been observed that if academicians experience stress cause of high level of demands of their job then it became difficult for institutions to retain and recruit a professional academicians' staff. The educational institutions have an important role in grooming young talent. Nowadays the emotional exhaustion, Organizational commitment, and loyalty have been received as emerging issue in the education sectors of a country and needs more attention to study the relationships between these constructs (Begley \& Czajka, 1993). Burnout affects the employees, whereas organizational commitment protected the employees within the organization (Kobasa \& Puccetti, 1983). Therefore, the current study explored the relationship between emotional exhaustion and organizational commitment. On the other side, organizational commitment is a protective factor to promote the positive academicians' outcomes and avoid burnout from both the individual and organization.

As per fundamental reasons of the conservation of resources and social exchange theory, it is recommended that if academicians are provided a high level of justice from institutions while providing teaching services then negative impact of emotional exhaustion on organizational loyalty can possibly be reduced in force. In the current era, most of the people interact with service sectors and because these professions require exposure to more 
interpersonal and social demands and require more emotional labor so, it would not be unjust to say that employees in service sectors experience more emotional exhaustion than others. The employees in these certain working sectors (e.g. nursing, home care, hoteling and teaching) are especially prone to it. In the teaching profession, the academicians are subject to a variety of stressors which enforce them to give up their daily routine work and also result in the development of burnout like symptoms, in simple words the academicians start facing physical and psychological symptoms which block their work and performance. To cope these situations, we conducted research to examine the moderating roles of organizational justice between the emotional exhaustion and job-related outcomes such as; organizational commitment and loyalty.

In a contribution to the previous research, we also considered organizational commitment as important as organizational loyalty as the dependent variable. Previous research has focused only on one outcome variable i.e. organizational loyalty. This study has been replicated to examine whether previous study's results are generalized to academicians and understudy organizational outcomes, such as commitment and loyalty. The purpose of this research study is to examine the moderating roles of organizational justice between the relationship of emotional exhaustion and job-related outcomes.

\section{Literature Review}

\section{A. Emotional Exhaustion and Teachers' Learning}

Emotional exhaustion has been defined as a state of constant burning of emotions as well as physical energy due to overwhelmed job demands (Bacharach, Bamberger, \& Conley, 1991). Furthermore, Teachers' learning can be described as the teaching experiences which are intended to perform in order to meet the learner's outcomes (Tyner, 2014). The current study proposed that Emotional exhaustion and teachers learning have a significant and negative relationship as if an employee whose profession demands emotions will continuously appeal the audience with positive as well as negative emotions (Kumashiro, 2015; Tyner, 2014). It became obvious to get exhausted and cause decreased teachers learning in the workplace where regularly various emotional and psychological demands have to face in day to day activities. Yet, fewer research studies have been done on checking the significant and negative relationship among emotional exhaustion and teacher's learning. Therefore, it is of main concern to check the effectiveness of this relationship under the current study. 
H1: There is a significant and negative relationship between emotional exhaustion and teachers' learning

\section{B. Emotional Exhaustion and Organizational Loyalty}

Organizational loyalty is basically an employee's recognition with his organization (Brief \& Motowidlo, 1986) proposed that if an employee feeling his work full of stress and facing psychological and emotional demands he becomes emotionally exhausted and results in decreased loyalty this, in turn, will increase employees' turnover intention. But if an employee has a strong level of organizational loyalty it is expected that he will remain with the organization even if any uncomfortable situations occur due to a temporary mishap (Karatepe, Yorganci, \& Haktanir, 2009). Yet, less research has been done on academicians to check that how they may feel stress and what will be their work-related outcomes and how these affect their loyalty. Thus, it has become important to study the association between emotional exhaustion and organizational loyalty to determine their stress level and its negative impact on academician's loyalty.

H2: There is a significant and negative relationship between emotional exhaustion and loyalty

\section{Emotional Exhaustion and Employee Commitment}

Emotional exhaustion and organizational commitment have a negative relationship (Khan et al., 2014). As, if employees in organization face excessive demands on their time and energy they seem less committed to their job as well as organizational goals. Furthermore, (Mukherjee et al., 2009) revealed in their recent study that emotional exhaustion may have harmful effects on employees' health as well as organizational processes, which may have negative job outcomes, such as; decreased performance, lower level job satisfaction and this will cause of reduced commitment towards organization. Previous studies have examined the impact of emotional exhaustion on other job-related outcomes such as job satisfaction, OCB, performance etc. we contribute to these studies by adding other relevant variables e.g. loyalty and commitment. And examine their association by examining umpiring role of organizational justice between the combinations of these three variables. Academicians shall be our subject to examine the above-mentioned relationship.

H3: There is a significant and negative relationship between emotional exhaustion and commitment 
Pakistan Journal of Humanities and Social Sciences, 6(2), 2018

The findings suggested that distributive justice plays umpiring role among the emotional exhaustion and organizational loyalty relationship, in such a way that these two variables' association becomes weaker negative (Hur et al., 2014). By considering the joint effect of conservation of resources and social exchange theory, an employee invests his intangible resources into an organization (e.g. struggle, endeavor) if he feels that he is being rewarded fairly against invested resources then he will possibly be motivated to invest more to find such outcomes (Harrell, 2000). Moreover, organizational justice plays a significant role to shape employees' outcomes (Ahmad, Nisar, \& Naqvi, 2016; Asif, Nisar, Faisal, \& Khalid, 2017). Generally, individuals which are the victims of workplace stressors who genuinely are working in unjust work environment actually unjust workplace lacks resource regeneration, and cause generation of employee sensitivity towards anxiety, stress and other negative attitudinal and behavior outcomes (Schaufeli, 2006). As per empirical results, distributive justice was found as a referee between emotional exhaustion and work-related outcomes relationship (Janssen, Lam, \& Huang, 2010). Our study will attempt to examine these relationships by getting responses from academicians rather than any other that has been previously examined. On the basis of previous literature, we have developed the following hypothesis.

H4(a): Distributive justice moderates the relationship between emotional exhaustion and jobrelated outcomes

By following the study's result, it has been argued that if an employee has a positive perception about return generation process in the organization it may cause to minimize negative association in emotional exhaustion and organizational loyalty (Hur et al., 2014). If we consider SET and the COR theory,(Barclay et al., 2005) which suggested that the negative association among emotional exhaustion and job-related outcomes may be strengthened if fairness perception of the employee about reward allocation procedure is negative. Under this consideration, researchers identified the violation of procedural justice can cause the several negative emotional outcomes including anger, aggressiveness, and resentment, which can reduce employee commitment. On the other hand, when employees are provided by sufficient amount of emotional and cognitive resources, their job performance go up and a sense of commitment towards the job and organizational goals is developed among them (Janssen et al., 2010). This hypothesis is developed based on the previous debate. 
H4(b): Procedural justice moderates the relationship between emotional exhaustion and jobrelated outcomes.

The study's findings suggested, an employee in the phase of facing various stressors due to job demands became exhausted and could not maintain his level of loyalty and commitment towards his job as well as organizational goal but if he is provided with respect, care and dignity then it will compel him to get back his replenished loyalty and commitment (Baron, Harris, Elliott, Schoefer, \& Ennew, 2005). Moreover, (Janssen et al., 2010) studied that existence of interactional justice grants a broader emotional positivity, strong connection, and communication with coworkers and other subordinates which in turn decrease the negativity between the association of emotional exhaustion and job-related outcomes. The developing sense attachment and connectedness also affect job performance and defines how emotional exhaustion and outcomes relationship is moderated by organizational justice (Egan, Yang, \& Bartlett, 2004). An organization which focuses on treating its employees with dignity and respect will generate positive emotions among employees such as enthusiasm, job satisfaction, loyalty and commitment that enable an employee to polish his/her social as well as psychological abilities and help in refreshing its replenished resources (Colquitt, Conlon, Wesson, Porter, \& Ng, 2001).

H4(c): Interactional justice moderates relationship between emotional exhaustion and jobrelated outcomes.

Few studies identified the moderating role of justice in the relationship of emotional exhaustion and teachers' learning (Schermuly \& Meyer, 2016). It has been observed that teaching profession which demands emotional as well as psychological involvements in routine activities and generate stressful consequences can make the employee overwhelmed of his/her job (Brown, Vesely, Mahatmya, \& Visconti, 2017) and cause lower teachers' learning and ultimately it affects them not to properly share their intended ideas that can fully meet the learning outcomes. So, the justice may increase learning and help to generate fruitful learning outcomes (Kearney et al., 2017). Yet, less research work has been observed in examining the moderating role of justice between the relationship of emotional exhaustion and teachers' learning in the teaching profession. Hence, the current study has been attempted to check the moderating role of organizational justice between the association of emotional exhaustion and teachers' learning. 
Figure 1: Research Model

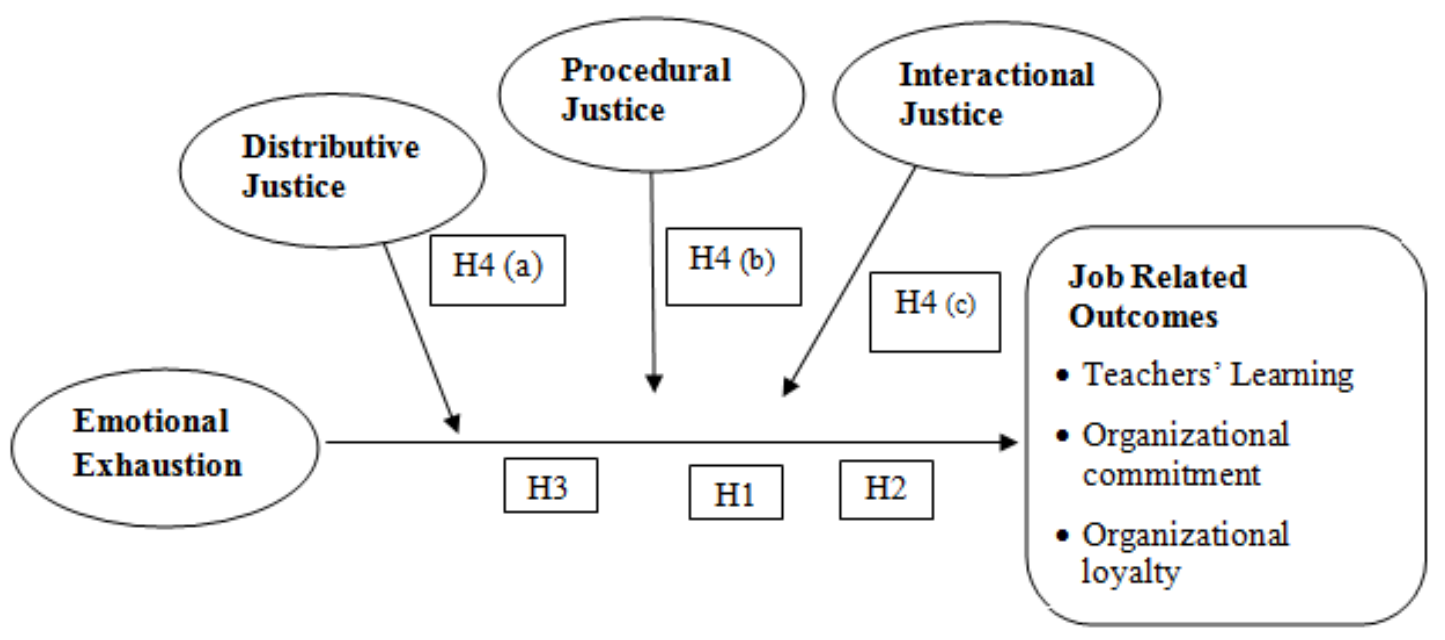

\section{Methodology}

This study demonstrates and examines the moderating role of organizational justice in the relationship of emotional exhaustion and job-related outcomes (teachers' Learning, organizational commitment, and loyalty. Scales from prior studies have been utilized to operationalize all under study variables.

\section{A. Questionnaire design}

The questionnaire is used in the survey. The questionnaire comprised of two segments. First, segment deals with respondents' personal profile which comprises of their age, gender, and education, nature of employment and length of service. The nominal scale was used to measure all these items. The second segment, deal with the understudy variables including organizational commitment, loyalty, organizational justice and emotional exhaustion. These constructs were measured by using Five-point Likert-type scales.

\section{B. Measures}

In order to measure organizational commitment (Meyer \& Allen, 1991) instrument has been utilized. 8 items instrument (Maslach\& Jackson, 1981) was adopted to measure emotional exhaustion. 3 items scale was utilized to measure organizational loyalty (Rutherford et al., 2012; Mowday et al., 1979). Moreover, justice and procedural justice were assessed by utilizing 3 items scale (Price \& Mueller 1986; Daly, 1995). Respectively. The Interpersonal justice was determined with the help 4 items scale (Moorman, 1991).

\section{Sampling}

Our target population is Govt. academicians in District Sialkot. As for a sample size is concerned, (Hair et al., 2010) suggested a thumb rule in order to consider sample size that 
can be obtained by multiplying the total items in a questionnaire by 10 . So, by following his method sample size for the current study is 250 from the same population. Data has been collected by applying simple random sampling technique.

\section{Data collection procedure}

For the purpose of data collection, the list of Government academies was obtained in District Sialkot from the official website and selects 20 institutions and these educational institutions were colleges. Then by using simple random sampling technique, we have distributed 250 questionnaires out of which 200 questionnaires were received out of which 7 have missing values and 9 were incomplete.

\section{E. Demographics}

Demographic section depicts the information about respondents' gender, age, and education level, nature of employment and length of service. Female filled 150 and male filled 50 questionnaires with the percentage of $75 \%$ and $25 \%$ respectively. Most of the respondents were between $26-45$ age group whose percentage is $47 \%$. Following to this age group of up to 25 , age group of $46-55$, and 56 or above and their percentages are of $19 \%$, $32 \%$, and 2\% respectively. Furthermore, Bachelors', Masters' and other educational level respondent's filled questionnaires their percentages are $37.5 \%, 53 \%$, and $9.5 \%$ respectively. The percentage of respondents who were permanent employees, contractual employees and visiting were 55\%, 26\%, and 19\% respectively. Respondents who have 2-5 years length of service are $25 \%$ and others who have 5-10 years, up to 1 year and more than 10 years length of service was of $30 \%, 16.5 \%$, and $28 \%$ respectively.

\section{Results}

Table 1 demonstrates that the EE is negatively correlated with distributive justice $(r=-.263)$, procedural justice $(r=-.240)$, interactional justice $(r=-.341)$, employees commitment $(r=-.425)$ and employees loyalty $(r=-.328)$. In addition, the Employees commitment was positively correlated with all variables i.e. employees loyalty $\left(r_{T 1}=.264\right)$, distributive justice $(r=.328)$, procedural justice $\left(r_{T 1}=.423\right)$ and interactional justice $\left(r_{T 1}=.356\right)$. It showed significant correlation among predictors and endogenous variables.

The results shown in table 2 illustrates that the majority values of factor loading are greater than 0.7. As per results, our scale convergent is reliable which means that the items showing variances are for their own variables that the other. This adds to the reliability factor of the study and relationship of the variables involved. 
Pakistan Journal of Humanities and Social Sciences, 6(2), 2018

Table 1: Descriptive \& Correlation Analysis

\begin{tabular}{|l|l|c|c|l|l|l|l|l|l|l|l|}
\hline & Construct & Mean & SD & $\mathbf{\alpha}$ & $\mathbf{l}$ & $\mathbf{2}$ & $\mathbf{3}$ & $\mathbf{4}$ & $\mathbf{5}$ & $\mathbf{6}$ & $\mathbf{7}$ \\
\hline 1 & Emotional Exhaustion & 2.76 & .63 & .712 & --- & & & & & & \\
\hline 2 & Distributive Justice & 4.64 & .87 & .887 & $-.265^{* *}$ & --- & & & & & \\
\hline 3 & Procedural Justice & 2.63 & .76 & .793 & $-.242^{* *}$ & .217 & --- & & & & \\
\hline 4 & Interactional Justice & 3.89 & .55 & 737 & -.344 & $.352^{* *}$ & $.167^{*}$ & & & & \\
\hline 5 & Employees Commitment & 4.56 & .59 & .782 & $-.427^{* *}$ & $.331^{* *}$ & $.425^{*}$ & $.357^{* *}$ & & & \\
\hline 6 & Employees Loyalty & 3.72 & .63 & .759 & $-.329^{* *}$ & $.265^{* *}$ & $.374^{* *}$ & $.369^{*}$ & $.266^{*}$ & --- & \\
\hline 7 & Teachers' Leaming & 3.87 & .76 & .790 & $-.398^{* *}$ & $.187^{*}$ & $.210^{* *}$ & $.187^{*}$ & $.235^{*}$ & .187 & -- \\
\hline
\end{tabular}

Table 2: Factor Loading

\begin{tabular}{|c|c|c|}
\hline Constructs & Items & Factor Loadings \\
\hline Emotional Exhaustion & 8 & $.868, .845, .781, .822, .834, .891, .886, .764$ \\
\hline Distributive Justice & 3 & $.887, .823, .734$ \\
\hline Procedural Justice & 3 & $.766, .738, .789$ \\
\hline Interactional Justice & 4 & $.8345, .796, .762, .942$ \\
\hline Employees Commitment & 4 & $.754, .812, .822, .845$ \\
\hline Employees Loyalty & 3 & $.878, .812, .656$ \\
\hline Teachers' Learning & 5 & $.765, .872, .776, .874, .753$ \\
\hline
\end{tabular}

Table 3 is representing the discriminant and convergent validity of the model as the values of AVE and composite reliability are greater than 0.5 and 0.8 respectively. Furthermore, the values of the square root of AVE are greater than the correlation value, that's why this model has convergent and discriminant validity.

Table 3: Psychometric Analysis

\begin{tabular}{|c|l|l|l|l|l|l|l|l|l|}
\hline & CR & AVE & EE & DJ & PJ & IJ & EC & EL & TL \\
\hline Emotional Exhaustion & 0.949 & 0.802 & $\mathbf{0 . 8 2 4}$ & & & & & & \\
\hline Distributive Justice & 0.857 & 0.668 & 0.411 & $\mathbf{0 . 7 4 5}$ & & & & & \\
\hline Procedural Justice & 0.808 & 0.585 & 0.523 & 0.321 & $\mathbf{0 . 7 5 4}$ & & & & \\
\hline Interactional Justice & 0.902 & 0.699 & 0.601 & 0.664 & 0.533 & $\mathbf{0 . 7 5 8}$ & & & \\
\hline Employees Commitment & 0.883 & 0.654 & 0.411 & 0.543 & 0.437 & 0.691 & $\mathbf{0 . 7 3 0}$ & & \\
\hline Employees Loyalty & 0.828 & 0.620 & 0.523 & 0.321 & 0.528 & 0.662 & 0.692 & $\mathbf{0 . 7 6 0}$ & \\
\hline Teachers' Learning & 0.905 & 0.656 & 0.476 & 0.235 & 0.198 & 0.218 & 0.534 & 0.356 & $\mathbf{0 . 6 6 5}$ \\
\hline
\end{tabular}

Table 4 is presenting the results of model fitness from both CFA and SEM dimensions. The goodness of fit index is given at the first place which represents the variance-covariance matrix and as its value is greater than 0.90 so it is declaring a good fit of the model. AGFI is adjusted GFI whose value is greater than 0.8 which is quite good to prove that model is a good fit. CFI is representing the comparative fit index which is showing more realistic values that are proving that model is near to absolute fit due to greater than 0.9 value. RMSEA is the root mean square error of approximation whose value is less than 0.10 so that is also indicating the good fitness model. 
Table 4: Fit Indices for CFA \& SEM

\begin{tabular}{|c|c|c|}
\hline Fit Indices & CFA & SEM \\
\hline Cmin/df & 3.06 & 2.99 \\
\hline GFI & 0.93 & 0.94 \\
\hline AGFI & 0.81 & 0.87 \\
\hline CFI & 0.94 & 0.96 \\
\hline RMSEA & 0.07 & 0.06 \\
\hline
\end{tabular}

Table 5 shows regression weights and significance level for relationship hypothesized in $\mathrm{h} 1, \mathrm{~h} 2$ and $\mathrm{h} 3$. Results provide an evidence that emotional exhaustion has a negative and significant impact on employees' commitment $(p<0.05)$, employee loyalty $(p<0.05)$ and teachers' learning $(p<0.05)$. These findings supported hypotheses H1, H2 and H3.

Table 5: SEM Regression Analysis

\begin{tabular}{|l|l|l|l|l|l|l|}
\hline & & & Estimate & S.E. & C.R. & P \\
\hline Employees Commitment & $<--$ & Emotional Exhaustion & -.516 & .091 & 5.67 & .01 \\
\hline Employees Loyalty & $<--$ & Emotional Exhaustion & -.498 & .080 & 6.22 & .02 \\
\hline Teachers' Leaming & $<--$ & Emotional Exhaustion & -.397 & .079 & 5.02 & .02 \\
\hline
\end{tabular}

\section{Moderation Analysis}

\section{A. Moderating Role of Distributive Justice on the relationship between Emotional Exhaustion \& Job-Related Outcomes}

The table 6 identifies that distributive justice significantly moderates on the relationship of emotional exhaustion and job-related outcomes (organizational commitment, organizational loyalty) as interaction term is significant $(\mathrm{p}<0.05)$ and change in $\mathrm{R}^{2}$ is $6 \%$ which indicates that distributive justice played moderating role and strength this relationship.

Table 6

\begin{tabular}{|c|c|c|c|c|c|}
\hline & $\mathbf{R}^{2}$ change & F & df1 & df2 & P \\
\hline Interaction & .06 & 11.3 & 1.0 & 100.0 & .02 \\
\hline
\end{tabular}

\section{B. Moderating Role of Procedural Justice on the relationship between Emotional Exhaustion \& Job-Related Outcomes}

The table 7 identifies that procedural justice significantly moderates on the relationship of emotional exhaustion and job-related outcomes (organizational commitment, organizational loyalty) as interaction term is significant $(\mathrm{p}<0.05)$ and change in $\mathrm{R}^{2}$ is $4 \%$ which indicates that procedural justice played moderating role and strength this relationship.

Table 7

\begin{tabular}{|c|c|c|c|c|c|}
\hline & $\mathbf{R}^{2}$ change & F & df1 & df2 & P \\
\hline Interaction & .04 & 12.1 & 1.0 & 124.7 & .01 \\
\hline
\end{tabular}




\section{Moderating Role of Interactional Justice on the relationship between Emotional Exhaustion \& Job-Related Outcomes}

The table 8 identifies that interactional justice significantly moderates on the relationship of emotional exhaustion and job-related outcomes (organizational commitment, organizational loyalty) as interaction term is significant $(\mathrm{p}<0.05)$ and change in $\mathrm{R}^{2}$ is $6 \%$ which indicates that interactional justice played moderating role and strength this relationship.

Table 8

\begin{tabular}{|c|c|c|c|c|c|}
\hline & $\mathbf{R}^{2}$ change & $\mathbf{F}$ & df1 & df2 & P \\
\hline Interaction & .06 & 10.1 & 1.0 & 139.0 & .02 \\
\hline
\end{tabular}

\section{Discussion and Conclusion}

Our study's aim is to examine the moderating (umpiring) role of organizational justice between the relationship of emotional exhaustion and job-related outcomes (teachers' learning, organizational commitment, and loyalty. Results identified that emotional exhaustion is significantly and negatively associated with teachers' learning and supported to H1. The findings divulged that there is a significant and negative relationship between emotional exhaustion and loyalty by supporting $\mathrm{H} 2$. It summed up that if an academician felt emotional exhaustion due to overwhelmed demands made on his/her psychological and physical energy during job then it will cause diminish in loyalty for that institute. These results have been supported by some previous studies (Hur et al., 2014; Brief \& Motowidlo, 1986). The findings summed up that there is also a significant and negative relationship between emotional exhaustion and commitment and supporting H3. It means if an academician felt emotionally exhausted due to overwhelmed demands on the job then it will cause a decrease in commitment for that institute. These results have been supported by some previous studies (Khan et al., 2014; Mukherjee et al., 2009).

Study findings enlightened that distributive justice moderates the relationship between emotional exhaustion and job-related outcomes and supporting H4(a). It defines that if an academician perceives the fairness of outcomes he/she receives, then organizational loyalty and commitment in relation with exhaustion will weaker in diminishing. Some previous studies have also supported our findings such as (Konovsky \& Cropanzano, 1991; Schaufeli, 2006; Janssen, Lam, \& Huang, 2010). Furthermore, our findings described that procedural justice moderates the relationship between emotional exhaustion and job-related outcomes. It means if an academician perceives the fairness of procedures to determine outcomes that he/she receives, then organizational loyalty and commitment in relation with 
exhaustion will weaker in diminishing. Some previous studies have also supported our findings such as (Hur et al., 2014; Barclay, Skarlicki, \& Pugh, 2005; Barclay et al., 2005). The findings also summed up that interpersonal justice moderate the relationship between emotional exhaustion and job-related outcomes. It explains, if academicians perceive that they are treated with respect and care by their coworkers and other subordinates then organizational loyalty and commitment in relation with exhaustion will weaker in diminishing. These studies also support our findings (Baron, Harris, \& Ennew, 2005; Janssen et al., 2010; Colquitt, Conlon, \& Ng, 2001).

\section{Practical implication}

This research provides an insight understanding about the growing need of justice to the academicians during their job when they feel overwhelmed demands made on their psychological and mental resources to invest. Education is the basic need for the social or economic growth of a nation. So, it's necessary for the institutions to provide as much as consideration to academicians (whether in terms of money or care) as they give other field members in order to maintain their loyalty and commitment toward the institute. So, education institutions can utilize our findings in the way that how much distributive, procedural, and interactional justice can cause academicians to maintain their loyalty and commitment when they feel emotional exhaustion during the job.

\section{Limitations and future directions}

In future, the researchers can expand this study by taking other dimensions of burnout as the independent variable. They can add other employee and organizational outcomes e.g. turnover intentions, physical health, job satisfaction, job performance, work attitudes and Organizational Citizenship Behaviors. Furthermore, the perceived supervisor support, intrinsic \& extrinsic reward, and perceived organizational support can be taken as moderators. Future studies can be carried out with large sample size with time horizon cross-sectional. Moreover, the study can be replicated by the researchers in other cultures and cross-national level. 
Pakistan Journal of Humanities and Social Sciences, 6(2), 2018

\section{References}

Ahmad, S., Nisar, Q. A., \& Naqvi, S. M. (2016). Effect of psychological contract fulfillment and organizational justice on employee reactions under moderation by organizational trust: a study on the lady health workers in Pakistan. Science International, 28(1).

Asif, M., Nisar, Q. A., Faisal, H. M., \& Khalid, H. (2017). Does Corporate Social Responsibility influence the Organizational Citizenship Behavior and Organizational Commitment? Mediating Role of Organizational Trust \& Organizational Justice. Conference Proceedings.

Bacharach, S. B., Bamberger, P., \& Conley, S. (1991). Work-home conflict among nurses and engineers: Mediating the impact of role stress on burnout and satisfaction at work. Journal of Organizational Behavior, 12(1), 39-53.

Bacharach, S. B., Bamberger, P., \& Conley, S. (1991). Work-home conflict among nurses and engineers: Mediating the impact of role stress on burnout and satisfaction at work. Journal of Organizational Behavior, 12(1), 39-53.

Barclay, L. J., Skarlicki, D. P., \& Pugh, S. D. (2005). Exploring the role of emotions in injustice perceptions and retaliation. Journal of Applied Psychology, 90(4), 629.

Baron, S., Harris, K., Elliott, D., Schoefer, K., \&Ennew, C. (2005). The impact of perceived justice on consumers' emotional responses to service complaint experiences. Journal of Services Marketing, 19(5), 261-270.

Begley, T. M., \&Czajka, J. M. (1993). Panel analysis of the moderating effects of commitment on job satisfaction, intent to quit, and health following organizational change. Journal of Applied Psychology, 78(4), 552.

Bies, R. J., \&Moag, J. S. (1986). Interactional justice: Communication criteria of fairness. Research on negotiation in organizations, 1(1), 43-55.

Boles, J. S., Johnston, M. W., \& Hair Jr, J. F. (1997). Role stress, work-family conflict and emotional exhaustion: Inter-relationships and effects on some work-related consequences. Journal of Personal Selling \& Sales Management, 17(1), 17-28.

Brief, A. P., \& Motowidlo, S. J. (1986). Prosocial organizational behaviors. Academy of management Review, 11(4), 710-725.

Brown, E. L., Vesely, C. K., Mahatmya, D., \& Visconti, K. J. (2017). Emotions matter: the moderating role of emotional labour on preschool teacher and children interactions. Early Child Development and Care, 1-15.

Cohen-Charash, Y., \& Spector, P. E. (2001). The role of justice in organizations: A metaanalysis. Organizational Behavior and Human Decision Processes, 86(2), 278-321.

Cole, M. S., Bernerth, J. B., Walter, F., \& Holt, D. T. (2010). Organizational justice and individuals' withdrawal: Unlocking the influence of emotional exhaustion. Journal of Management Studies, 47(3), 367-390.

Colquitt, J. A. (2001). On the dimensionality of organizational justice: a construct validation of a measure. Journal of Applied Psychology, 86(3), 386.

Colquitt, J. A., Conlon, D. E., Wesson, M. J., Porter, C. O., \& Ng, K. Y. (2001). Justice at the millennium: a meta-analytic review of 25 years of organizational justice research. Journal of Applied Psychology, 86(3), 425. 
Cropanzano, R., Rupp, D. E., \& Byrne, Z. S. (2003). The relationship of emotional exhaustion to work attitudes, job performance, and organizational citizenship behaviors. Journal of Applied Psychology, 88(1), 160.

Daly, J. P. (1995). Explaining changes to employees: The influence of justifications and change outcomes on employees' fairness judgments. The Journal of applied behavioral science, 31(4), 415-428.

Demerouti, E., Bakker, A. B., Nachreiner, F., \& Schaufeli, W. B. (2001). The job demandsresources model of burnout. Journal of Applied Psychology, 86(3), 499.

Dicke, T., Parker, P. D., Marsh, H. W., Kunter, M., Schmeck, A., \& Leutner, D. (2014). Selfefficacy in classroom management, classroom disturbances, and emotional exhaustion: A moderated mediation analysis of teacher candidates. Journal of Educational Psychology, 106(2), 569.

Diestel, S., \& Schmidt, K.-H. (2011). Costs of simultaneous coping with emotional dissonance and self-control demands at work: results from two German samples. Journal of Applied Psychology, 96(3), 643.

Egan, T. M., Yang, B., \& Bartlett, K. R. (2004). The effects of organizational learning culture and job satisfaction on motivation to transfer learning and turnover intention. Human resource development quarterly, 15(3), 279-301.

Folger, R., \& Greenberg, J. (1985). Procedural justice: An interpretive analysis of personnel systems. Research in personnel and human resources management, 3(141-183).

Gaines, J., \& Jermier, J. M. (1983). Emotional exhaustion in a high stress organization. Academy of Management Journal, 26(4), 567-586.

Halbesleben, J. R., \& Bowler, W. M. (2007). Emotional exhaustion and job performance: the mediating role of motivation. Journal of Applied Psychology, 92(1), 93.

Harrell, S. P. (2000). A multidimensional conceptualization of racism-related stress: implications for the well-being of people of color. American Journal of Orthopsychiatry, 70(1), 42.

Hendrix, W. H., Robbins, T., Miller, J., \& Summers, T. P. (1998). Effects of procedural and distributive justice on factors predictive of turnover. Journal of Social Behavior \& Personality.

Hochschild, A. R. (2012). The managed heart: Commercialization of human feeling: Univ of California Press.

Hur, W.-M., IL Park, S., \& Moon, T.-W. (2014). The moderating roles of organizational justice on the relationship between emotional exhaustion and organizational loyalty in airline services. Journal of Services Marketing, 28(3), 195-206.

Janssen, O., Lam, C. K., \& Huang, X. (2010). Emotional exhaustion and job performance: The moderating roles of distributive justice and positive affect. Journal of Organizational Behavior, 31(6), 787-809.

Karatepe, O. M., Yorganci, I., \&Haktanir, M. (2009). Outcomes of customer verbal aggression among hotel employees. International Journal of Contemporary Hospitality Management, 21(6), 713-733. 
Pakistan Journal of Humanities and Social Sciences, 6(2), 2018

Kearney, T., Kearney, T., Walsh, G., Walsh, G., Barnett, W., Barnett, W., . . Schwabe, M. (2017). Emotional intelligence in front-line/back-office employee relationships. Journal of Services Marketing, 31(2), 185-199.

Khan, F., Rasli, A. M., Yusoff, R. M., Faizan Malik, M., Muddassar Khan, M., \& Khan, Q. (2014). Effect of emotional exhaustion on organizational commitment among academicians. Science International, 26(5).

Khan, N. Z. A., Imran, A., \& Nisar, Q. A. (2016). Emotional Exhaustion as Stressor agent for Job Stress in Call Centers: Empirical evidence from perspective of Job Satisfaction and Turnover Intention as Work Outcomes. European Online Journal of Natural and Social Sciences, 5(4), 908.

Kobasa, S. C., \&Puccetti, M. C. (1983). Personality and social resources in stress resistance. Journal of personality and social psychology, 45(4), 839.

Konovsky, M. A., \&Cropanzano, R. (1991). Perceived fairness of employee drug testing as a predictor of employee attitudes and job performance. Journal of Applied Psychology, 76(5), 698.

Kumashiro, K. K. (2015). Against common sense: Teaching and learning toward social justice: Routledge.

Mahesar, H. A., Chaudhry, N. I., Ansari, M. A., \& Nisar, Q. A. (2016). Do Islamic HRM Practices Influence Employee Outcomes: Mediating Role of Employee Engagement. International Research Journal of Arts and Humanities, 44(44), 85.

Maslach, C., \& Jackson, S. E. (1981). The measurement of experienced burnout. Journal of occupational behavior, 2(2), 99-113.

Maslach, C., Jackson, S. E., \& Leiter, M. P. (1986). Maslach burnout inventory.

Mattila, A. S., \& Patterson, P. G. (2004). Service recovery and fairness perceptions in collectivist and individualist contexts. Journal of Service Research, 6(4), 336-346.

Meyer, J. P., \& Allen, N. J. (1991). A three-component conceptualization of organizational commitment. Human resource management review, 1(1), 61-89.

Moorman, R. H. (1991). Relationship between organizational justice and organizational citizenship behaviors: Do fairness perceptions influence employee citizenship?. Journal of applied psychology, 76(6), 845.

Mowday, R. T., Steers, R. M., \& Porter, L. W. (1979). The measurement of organizational commitment. Journal of vocational behavior, 14(2), 224-247.

Mukherjee, A., Malhotra, N., Ashill, N. J., Rod, M., Thirkell, P., \& Carruthers, J. (2009). Job resourcefulness, symptoms of burnout and service recovery performance: an examination of call centre frontline employees. Journal of Services Marketing, 23(5), 338-350.

Nett, U. E., Goetz, T., \& Hall, N. C. (2011). Coping with boredom in school: An experience sampling perspective. Contemporary Educational Psychology, 36(1), 49-59.

Ohue, T., Moriyama, M., \&Nakaya, T. (2011). Examination of a cognitive model of stress, burnout, and intention to resign for Japanese nurses. Japan Journal of Nursing Science, 8(1), 76-86. 
Porter, L. W., Steers, R. M., Mowday, R. T., \&Boulian, P. V. (1974). Organizational commitment, job satisfaction, and turnover among psychiatric technicians. Journal of Applied Psychology, 59(5), 603.

Rasli, F. K. A. M., Yusoff, R. M., \& Malik, M. F.(2014) Effect of emotional exhaustion on organizational commitment among academicians.

Rutherford, B. N., Wei, Y., Park, J., \& Hur, W. M. (2012). Increasing job performance and reducing turnover: An examination of female Chinese salespeople. Journal of Marketing Theory and Practice, 20(4), 423-436.

Schaufeli, W. B. (2006). The balance of give and take: Toward a social exchange model of burnout. Revue internationale de psychologiesociale(1), 75-119.

Schermuly, C. C., \& Meyer, B. (2016). Good relationships at work: The effects of LeaderMember Exchange and Team-Member Exchange on psychological empowerment, emotional exhaustion, and depression. Journal of Organizational Behavior, 37(5), 673-691.

Shirom, A. (1989). Burnout in work organizations.

Siegall, M., \& McDonald, T. (2004). Person-organization value congruence, burnout and diversion of resources. Personnel Review, 33(3), 291-301.

Singh, J. (2000). Performance productivity and quality of frontline employees in service organizations. Journal of marketing, 64(2), 15-34.

Spector, P. E. (1987). Method variance as an artifact in self-reported affect and perceptions at work: Myth or significant problem? Journal of Applied Psychology, 72(3), 438.

Tyler, T. R., \& Bies, R. J. (1990). Beyond formal procedures: The interpersonal context of procedural justice. Applied social psychology and organizational settings, 77, 98.

Tyner, K. (2014). Literacy in a digital world: Teaching and learning in the age of information: Routledge.

Wang, X., Liao, J., Xia, D., \& Chang, T. (2010). The impact of organizational justice on work performance: Mediating effects of organizational commitment and leadermember exchange. International Journal of manpower, 31(6), 660-677.

Wayne, S. J., Shore, L. M., \& Liden, R. C. (1997). Perceived organizational support and leader-member exchange: A social exchange perspective. Academy of Management Journal, 40(1), 82-111.

Weiss, H. M., Suckow, K., \& Cropanzano, R. (1999). Effects of justice conditions on discrete emotions. Journal of Applied Psychology, 84(5), 786.

Wilk, S. L., \& Moynihan, L. M. (2005). Display rule" regulators": the relationship between supervisors and worker emotional exhaustion. Journal of Applied Psychology, 90(5), 917.

Wright, T. A., \& Bonett, D. G. (1997). The contribution of burnout to work performance. Journal of Organizational Behavior, 18(5), 491-499. 